\title{
Using Gold Standard Project Based Learning for Intermediate Year Three Pupils to Enhance English Speaking Skill: A Conceptual Paper
}

\author{
Hanis Arini Mohamad Sayuti, Teh Guat Ann, Wan Mohd Suhairi Abdullah Saimi, \\ Mohd Asrafeel Bakar@Abu Bakar, Siti Nurzahidah Ahmad Dawawi, Maslawati Mohamad*
}

Universiti Kebangsaan Malaysia, Bangi, Malaysia

Email: ^maslawati@ukm.edu.my

How to cite this paper: Sayuti, H. A. M., Ann, T. G., Saimi, W. M. S. A., Bakar, M. A. B., Dawawi, S. N. A., \& Mohamad, M. (2020). Using Gold Standard Project Based Learning for Intermediate Year Three Pupils to Enhance English Speaking Skill: A Conceptual Paper. Creative Education, 11, 1873-1889.

https://doi.org/10.4236/ce.2020.1110137

Received: June 26, 2020

Accepted: October 11, 2020

Published: October 14, 2020

Copyright (c) 2020 by author(s) and Scientific Research Publishing Inc. This work is licensed under the Creative Commons Attribution International License (CC BY 4.0).

http://creativecommons.org/licenses/by/4.0/ (c) (i) Open Access

\begin{abstract}
The effectiveness of teaching methods has been studied by researchers around the globe. According to many past studies, Project Based Learning (PBL) is one of the teaching methods that benefit the pupils' performance in the classroom. One of the benefits is to enhance pupils' English speaking skill. In this paper, the researchers intend to provide literature review and past studies on Gold Standard Project Based Learning (GSPBL). GSPBL was designed by Buck Institute for Education. The findings of past studies indicate that GSPBL could assist English teachers to improve pupils' speaking practice during class activities. After investigating on how GSPBL could enhance the pupils' English speaking skill from the literature review, the researchers are proposing this study to be carried out at an urban government school in Kuala Lumpur. The objective of this research is to investigate pupils' speaking performance in English speaking skill before and after the implementation of Gold Standard Project Based Learning. There will be 30 of intermediate Year Three pupils involved in this study. The researchers will conduct a qualitative case study for eight weeks to investigate pupils' speaking performance before and after the implementation of Gold Standard PBL. Observation, interview and documents will be used as data collection tools. The documents are Classroom Based Assessment report. The data from the observation notes, interview responses and documents will be analysed thematically. The findings of this paper would benefit the English teachers with regard to equipping them with the measures to carry out GSPBL more effectively as classroom activity. Apparently, the pupils could also enhance their English language speaking skill after GSPBL has been introduced and implemented as their classroom activity.
\end{abstract}




\section{Keywords}

Year Three Pupils, English Speaking Skill, English as a Second Language, Gold Standard Project Based Learning

\section{Introduction}

In order to engage the pupils with a great and memorable learning experience, the teachers have come out with different types of methodology in their way of teaching such as assigning the pupils with a task or conducting activities for them to participate in order for the pupils to have a different kind of knowledge approach and experiences throughout the learning process. According to Munawaroh (2017), learning won't be compelling without a learning strategy.

One of the teaching methods that have been used among the pupils is Project Based Learning (PBL). PBL is a method of learning where the pupils engage with a real world and hands on project where they can apply their knowledge, ideas and skills throughout the process of completing the project (Buck Institute for Education, 2019). According to Nasrullah (2013) as cited by Cintang, Setyowati and Handayani (2017), the learning takes the pupils and teachers into genuine circumstance, genuine issues, and genuine arrangement so that the pupils cannot see obstacles between what they practise and study inside of the class or outside of the learning centre. Besides, by working on a project for a short or long period of time, the pupils also apply their prior knowledge of what they have learnt theoretically in class. Nevertheless, by assigning the pupils with Project Based Learning, it helps them to understand the concept of the lesson delivered in the class very well and can be seen visually throughout their experience in engaging with the process of the project completion.

In addition, Project Based Learning can develop pupils' level of knowledge as well as communication skills, creative and critical thinking, teamwork and others. This is because the pupils are engaging with the authentic materials, real life issues, complex solution and problems which can assist them to encounter every aspect that they have been facing throughout the PBL session between the pupils and also the teachers. PBL is an extensive way of teaching and learning method that is formed to keep the pupils in a track of difficult analysis, material problems and well composition of material and assignment (Baş \& Beyhab, 2017). Apart from engaging with various types of skills, PBL can also drill the pupils' higher order thinking skills to go beyond the way of the pupils' thinking.

However, it is a challenging task for a teacher to equip their pupils particularly with relevant speaking skills. The pupils have difficulties in their speaking due to lack of vocabulary, lack of self-confidence, afraid of making errors and no ideas about what to say. For the first difficulty, the pupils lack of vocabulary whereby it is difficult for them to express their thought verbally in the class. Secondly, their difficulty is their lack of self-confidence. They tend to be shy and uncom- 
fortable to speak in English with their teachers and their peers. Then, they are also afraid of making errors in class, because they feel shameful when they are being corrected in front of their friends. Lastly, they have no ideas about what to say. Due to these challenges, they tend to keep silent during the class session. The proposed study will be conducted in order to overcome the highlighted English speaking skill difficulties. Apart from this, the main purpose of the research is to link the use of GSPBL with the pupils' speaking performance in English speaking skill. This is in line with Linse (2005) mentioning that speaking is the first step that needs to be learned by young English language learners before they can read and write in English. This shows that speaking skill is an important skill used to communicate between the teacher and the pupils in a teaching learning process. This will help the pupils to understand better where they can either communicate to ask questions or to give opinions during the lesson. Aside from that, the pupils can use the skill in a real life situation where they can engage with the real world to communicate with the community around the globe.

The use of Project Based Learning in classroom generally affects the pupils' development and performance level in speaking skill. Thus, we proposed this study by using The Gold Standard Project Based Learning framework in enhancing pupils' speaking skill in English language classroom. Other related past studies on the use of PBL in enhancing English speaking skill are also included. The research question for this study is:

- How does Gold Standard PBL affect pupils' speaking performance in English speaking skill?

\section{Literature Review}

\subsection{Benefits of Project Based Learning}

Teaching and learning are not basically static. They are dynamic. There is no one absolute method in teaching and learning. Project Based Learning (PBL) is one of the methods. Project Based Learning or known as PBL is a teaching method where the students learn the skills and acquiring the knowledge in a period of time and it involves certain criteria (Buck Institute for Education, 2019). According to them, the criteria must be authentic, engaging, and complex question, problem, or challenge. PBL is known to be a better approach in learning compared to the standard "lecture" style because PBL lets the students to understand the curriculum and the content better (Barron et al., 1998; Baumgartner \& Zabin, 2008; Beneke \& Ostrosky, 2008; Blumenfeld, et al., 1991; Chu, Tse, \& Chow, 2011; Faris, 2008; Hertzog, 2007; Hmelo-Silver, Duncan, \& Chinn, 2007) as cited in Mahsan and Ibrahim (2017). Hence, PBL is a better way of learning either in terms of acquiring the knowledge or the skills (Mahsan \& Ibrahim, 2017). The pupils also have more chance to show their ability in understanding the content of the knowledge compared to the traditional way of peer learning (Barron et al., 1998; Baumgartner \& Zabin, 2008; Beneke \& Ostrosky, 2008; Blumenfeld et al., 1991; Chu, Tse, \& Chow, 2011; Faris, 2008; Hertzog, 2007; 
Hmelo-Silver, Duncan, \& Chinn, 2007) as cited in Mahsan and Ibrahim (2017). Hence, based on many studies that focus on the effectiveness of PBL in increasing the level of understanding of teaching and learning among the students has led Buck Institute for Education to introduce the Gold Standard PBL that comprises of Seven Essential Project Design Elements and Seven Project Based Teaching Practices.

PBL is known to be an effective method in learning based on several findings. In 2017, PBLWorks have conducted several researches and priority plan in improving the effects of PBL (Buck Institute for Education, 2019). Hence, in 2019, a case study has been conducted. It is to determine the students' outcome from high quality project based learning. The case study involves a chemistry teacher in a school and it involves 37 students. The result shows that PBL does have a positive impact (Evans, 2019). The teacher uses a guideline known as pathways in conducting the task.

The pathway consists of: (Figure 1)

The result shows that the students are showing positive improvement when PBL is applied in the lesson (Evans, 2019). There are several studies that share identical results such as Putri, Artini and Nitiasih (2017), Ong, Safiee, Mat Jusoh, Md Salleh and Mohamed Noor (2017), Ong, Ayob, Ibrahim, Adnan, Shariff and Ishak (2016). Moreover, the task given based on the PBL framework shows more engagement in completing a task given and acquiring new knowledge as well as active participation among students (Ong et al., 2017). Furthermore, one of the PBL elements is collaboration and the significant change in students' collaboration can also be seen while completing the task given (Putri et al., 2017). PBL requires students to have peer collaborations in completing the task given within a time frame. The collaborations may lead to the exchange of ideas and the students will be more actively engaged (Putri et al., 2017). The next element in PBL is reflection. Reflection is an important element in identifying the course of a project whether it is still on the right track or the other way round (Buck Institute for Education, 2019). In Malaysia, the introduction of Transformasi Sekolah 2025 or TS25 programme is to uphold the standard of teaching and learning in Malaysia (Ministry of Education, 2018). One of the modules, module 6 Kefahaman Melalui Rekabentuk or KMR, uses PBL as the core of it. It requires the participated schools to complete a task within a given time frame and present their project to public (Bahagian Pendidikan Guru, n.d.). This can be seen as a big move for the Malaysian education system in making the students to be more competitive globally.

\subsection{The Development of Speaking Skill in PBL}

There are several studies focusing on PBL. Those studies consist of multiple fields. One of them is the use of PBL in enhancing speaking skills. Speaking skills is one of the four major skills in English that can be considered as essential. Nunan (1995) and Sani, Manurung and Suswanto (2018) as cited in Nugroho and Anugerahwati (2018) agree that speaking is vital in order to communicate 


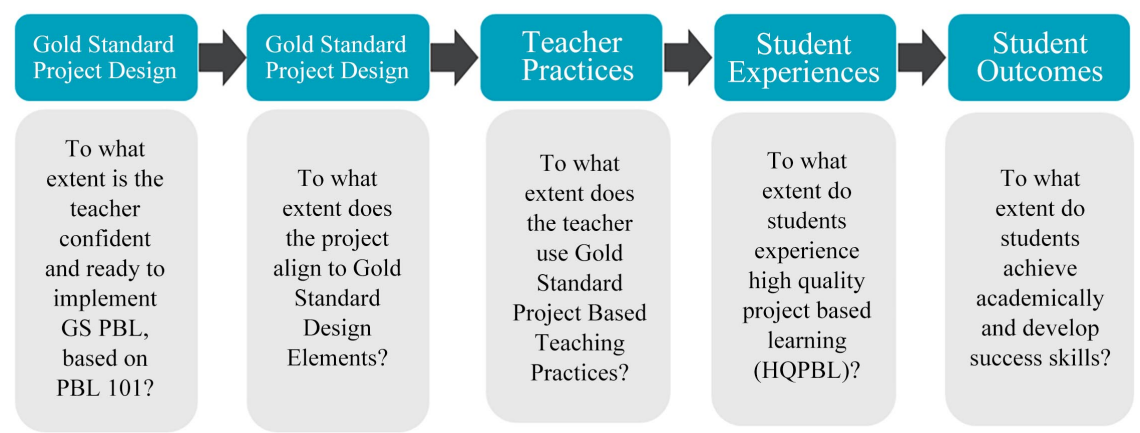

Figure 1. Pathway of PBL.

with others. Hence, there are many ways to improve speaking skills. Several studies have been conducted in determining ways to enhance speaking skills. One of them is PBL. According to Srikrai (2008) and Simpson (2011) as cited in Poonpon (2017), project based learning do enhance the students' language skills. The statement is also supported by Sanchez (2019) by stating that students' speaking skill is improved via PBL activities. If to refer to a particular skill, which is speaking, Zare-Behtash and Sarlak (2017) confirm that PBL does have a significant effect in enhancing speaking skill compared to the traditional way of teaching and learning process. This statement is also supported by Riswandi (2018) where it is stated that PBL improves not just the speaking skill, but the motivation of the students as well. Riswandi (2018) also states that the discussion occurring during group work improves the ability of the students to speak since they have to share their idea while the group work is being done. The discussion between peers could lessen the barrier for the students to practise their speaking thus giving them more room for improvement. Jaya, Hermansyah and Rosmiyati (2019) conclude that PBL enhances the students' ability in speaking from certain aspects such as language use anxiety, causal attribution and self-efficacy. They also conclude that the intervention of PBL gives the students the opportunity to explore and study their learning. This shows that the elements in PBL do contribute to the enhancement of English especially in speaking skills. In general, PBL is seen as a way of teaching and learning is being carried out. There is another approach that uses PBL as its main foundation with slight differences known as the Gold Standard PBL which has been introduced by Buck Institute for Education in 2019 which will be discussed in the next subtopic.

\subsection{The Elements of Gold Standard PBL (GSPBL) in Speaking Skill}

Based on the GSPBL (Figure 2), there are 8 elements in the new model. Those elements can be divided into two. One acts as the goal while the remaining seven act as the criteria of a GSPBL project. Key knowledge, understanding and success skill fall under the goal of GSPBL. Key knowledge and understanding show that teacher and pupils must "learn deeply, mastering knowledge and concepts" (Larmer, Mergendoller, \& Boss, 2015a: p. 3). In terms of speaking, teachers and pupils must really get the concept of it and fulfill the proposed goal. It is not just 


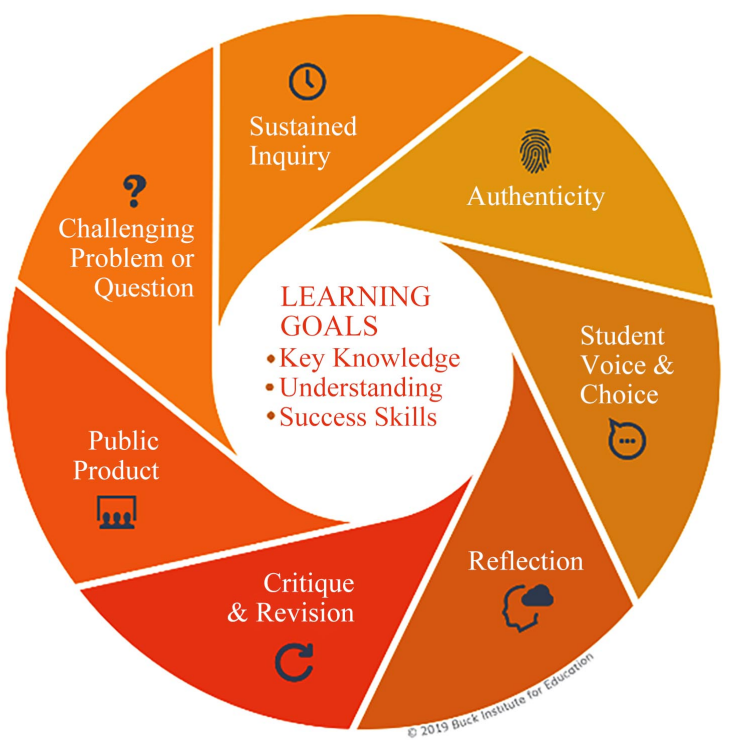

Figure 2. New model for gold standard PBL.

a brief understanding but more into a deep understanding that should be performed by the teachers and pupils. Larmer et al. (2015a) also state that key success is meant for the pupils to use their knowledge and understanding of the topic while doing the GSPBL for the future. If the pupils are learning speaking while doing the GSPBL, that speaking skill should be able to be used when they have finished the project.

The remaining seven project design elements are meant for the structure of the project. The first one is challenging problem or question. Larmer et al. (2015a) also state that questions and problems are essential in giving the pupils the purpose of learning. By this, the pupils will master the topic and they will know when and how to apply their knowledge. If the pupils master the speaking skill, they will know when to use the targeted language and how to apply their language skill in their daily life.

The next element is sustained inquiry. According to Larmer et al. (2015a), challenging problem or question is the element to launch sustained inquiry. $\mathrm{Pu}-$ pils must keep on asking question for their project every day. This will make them keep on researching the topic in depth. They will learn to study the speaking skill thoroughly. It will benefit them when it comes to structuring the language.

Authenticity is the next element to be discussed. Larmer et al. (2015a) state that authenticity means the problem or the task for the pupils must be related to the real life situation. It means the subject or the topic that they have chosen must be related to the real life and the knowledge can be applied in a real world situation. For instance, the topic for the development of speaking skill among the students can be applied when they are engaged with the community.

Pupils' voice and choice. Larmer et al. (2015a) argue that students must voice out their opinion while doing the project. It will be more meaningful or other- 
wise the project will turn out to be just like an exercise for them. In learning speaking, students must try to solve any problems occur during the project is being carried out without the help of the teachers. This will increase their understanding of the skill that they are learning.

The next one is reflection. According to Larmer et al. (2015a), they state that teachers and students must reflect on their goal, the inquiry process and the effectiveness of their project throughout the project. GSPBL aims to make the students to reflect on the problem that they encounter. As in speaking, students must reflect on the effectiveness of the approach that they are using if they have difficulties in carry out the project.

Then, move to the next element which is critique and revision. Larmer et al. (2015a) argue that every project based on GSPBL, the students must be prepared to receive any suggestion to improve their project because the idea from other is essential. For example, students must be ready if there is any suggestion to improve the project on speaking skill. It might come from the teachers or other experts that might see ways to improve the project.

The last one is public product. Public product means that the students will be able to share their product with public (Larmer et al., 2015a). It can be seen as a more engaging approach and it will also increase the project's authenticity. For speaking skill, the students can share their project with the audience that might find their project as useful and can be applied for other students as well.

\section{The Use of PBL for Pupils' Speaking Skill}

As mentioned in the previous paragraphs, various studies have shown the positive impact of Project Based Learning (PBL) as intervention of pupil's speaking skill especially in English subject. Based on Project Based Learning Handbook, PBL is one of the models for classroom activity that shifts away from the usual and traditional classroom practices of short, isolated and teacher-centred lessons. $\mathrm{PBL}$ is a teaching practice that starts to regain its place in the education field in line with the current changes of 21st century learning. According to Heick (2020), PBL is becoming a more popular trend in teaching especially in this modernized world which shifting from academic study to highly multiplex method that challenges pupil's way of thinking to solve the problems. Various past studies have been conducted to observe the implementation of PBL in enhancing pupil's speaking skill. There are few studies conducted in Indonesia and Columbia (Vaca Torres \& Gómez Rodríguez, 2017; Riswandi, 2018). Since there were limited past studies conducted in Malaysia which related to the intervention of Gold Standard PBL mentioned in the proposed study, therefore a few past studies in using PBL to improve speaking skill in Malaysia context were taken as example (Azlan, Zakaria, \& Yunus, 2019; Baruah, 2012).

\subsection{Other Related Past Studies on Using PBL as Intervention to Enhance Pupils' Speaking Skill}

PBL has been used by the teachers to help pupils to improve and enhance their 
language acquisition in English subject. Language acquisition involves the four basic skills which are listening, speaking, reading and writing. Each of the skills can be improved by using the PBL approach which should be adjusted to pupils' level of thinking. However, the focus skill of this study is only speaking skill as it is clearly stated in the research objective.

Project-based implementation has given positive impacts on the improvement of speaking skill among the students. Chomsky (1986) stated that children are naturally born with a Language Acquisition Devise (LAD) which enables them to pick up the language faster and effortlessly. As mentioned above, some past studies have been conducted before this to link the use of PBL with pupil's performance in speaking skill. An action research was employed by Riswandi (2018) aimed at describing to what extent the use of PBL can improve the pupil's speaking skill. Twenty eight respondents were chosen for this research and they are among the seventh-grade students of one of Junior High Schools in Surakarta. The researcher conducted the study with two cycles by using the data collection tools such as observation checklist, field notes, questionnaire and interview. The researcher confirmed the validity of the data by using the triangulation method in which the questionnaire and interview are administered to the selected students. The respondents completed four stages which used the term by Fauziati (2014) named starting with project, developing the project, reporting to the class and assessing the project. The finding based on the teacher's observation showed $95 \%-100 \%$ of the students contribute by sharing their ideas in the group task given. The researcher emphasized his study by stating, collaborating in group work has resulting in the betterment of their speaking fluency, vocabulary, pronunciation, grammar and content on what to speak. The researcher also addressed a limitation for this study which is some students are passive and this has affected the group work given. In the future, the researcher can provide some language support to help the passive students to communicate and participate better.

Besides that, Vaca Torres and Gómez Rodríguez (2017) examined how PBL enhanced the speaking skill among the EFL learners. The researcher conducted the action research among 30 ninth graders at a public school in Bogota, Colombia. The data were collected through field notes, transcripts of learner's oral performance and interview. The pedagogical intervention used required students to execute three projects in which they were encouraged to speak English based on the topic given that related to their personal lives and environment. They need to complete three cycles in which each cycle was given ample time to be conducted. They carried out the research by dividing it into 1) discovering who my classmates are: sharing common ideals and respecting differences, 2) Is everything fine at school? Making proposals to improve our school problems and 3) Getting involved in my neighbourhood. All the three cycles employed speaking formal of interview and oral presentation which help the students to communicate better. The main findings of the research showed that PBL encourage stu- 
dents to enhance oral skill through lexical competence development, help them to get control of the fear of speaking and increase their interest in learning about life and community.

Based on the reviewed studies, the common relation in the speaking skill is the usage of PBL. The findings of the above mentioned studies will be beneficial for us as we intend to replicate some of the earlier studies by using the Gold Standard PBL Framework by Larmer and Mergendoller (2015) in our proposed study for Malaysian pupils.

\subsection{Related Past Studies on Using Project Based Learning to Enhance Speaking Skill in Malaysia}

PBL has been widely used by educator but the published journal related to Gold Standard PBL Framework by Buck Institute Education (2015) is still quite limited in Malaysia. In this new world of $4^{\text {th }}$ industrial revolution, the delivery of knowledge or education are depending on the evolving technologies and generating new styles of teaching and different ways of assessment Azlan et al. (2019).

Therefore, a study by Azlan et al. (2019) suggested an integration of Instagram and task-based learning to be a medium for pupils to practice their speaking skill. This action research was conducted and was aimed to discover the potential use of Instagram features and PBL to develop pupil's speaking skill. For this study, an observation and semi structured interview were used to collect the data. The research involved eight pupils from an urban pre-school in Selangor and low level of English proficiency in a rural primary school in Negeri Sembilan. The research consisted of two cycles and was conducted over a period of 14 weeks. The PBL activities selected for this study are role-play, jazz chants and social expression that reflect on normal daily conversation. The respondents are required to record themselves by using the Instagram platform and talk about the topic given. From the study, the researchers found the integration of PBL and Instagram has given positive impact in developing pupil's speaking skill in which the platform portrays the skills of questioning, answering, imitating, singing, chanting and others. The findings above support that online social media helps in enhancing pupil's speaking skill in the academic institutions (Baruah, 2012). Lastly, the researcher highlighted the research gap by stating that it would be more beneficial if there is further study to be conducted with larger sample and include other pupils from secondary level especially from the rural areas.

The next relevant study is the study by Bakar, Noordin and Razali (2019) that aimed to investigate the effectiveness of PBL activities as a teaching approach to improve student's oral and communication skill. The research was conducted among 44 diploma students from a technical college in the Peninsular Malaysia. This quasi-experimental study used the data collection tools such as pre-test and post-test and questionnaire. Findings of the research showed a significant improvement in student's oral skill in which they were required to present their ideas through the group project such as discussion, role play, video response and 
pair discussion based on principles proposed by Larmer et al. (2015b). Overall the result of the study support that PBL has affected student's speaking skill positively.

Based on the studies above, it is the appropriate time to implement Gold Standard PBL in Malaysian school as the findings from past studies outside and in Malaysia show that implementation of PBL to improve English speaking skill is valid to a certain extent.

\section{The Proposed Study}

Based on the past studies and literature review, Project Based Learning (PBL) has been recognized to be effective in the $21^{\text {st }}$ century education. It has been proven to be helpful in facilitating students' personal growth, language skills, creative thinking and content learning as a great number of studies on PBL have been carried out globally (Lam, 2011). Levine (2004) stated that the most recognizes benefit of implementing PBL in a foreign language classroom is improved language skills. Compared to the old model of Project Based Learning, Gold Standard Project Based Learning has been improved to suit the needs of the $21^{\text {st }}$ century learning. Addition of authenticity and reflection to the new model poses a big impact in selecting this model to be implemented in the proposed study. Authentic project promises lifelong learning as the pupils will carry out project related to their daily life. Thus, by implementing authentic project, it helps a lot in enhancing pupils' speaking skill as they have the platform to practise it. Pupils need to communicate in an authentic environment for them to gain confidence and exchange thoughts based on their experience. Pupils have the chance to practise their language in natural context when they get engaged in purposeful communication and meaningful projects in order to complete the given authentic activities. The element of reflection after critique and revision is also important. Pupils would be given time to reflect on their work, to think about what and how to improve based on the critique provided. Pupils would also learn about the importance of their project and how the project affects the environment. This would promote a better learning as it helps pupils to improve their speaking skills during reflection session in groups.

\subsection{Methodology}

After a thoughtful consideration, the researchers are proposing to use Gold Standard Project Based Learning for Intermediate Year Three Pupils to enhance English Language Speaking Skill. The research question and research objective are as follow:

- Research question: How does Gold Standard Project Based Learning affect pupils' speaking performance in English speaking skill?

- Research objective: To investigate pupils' speaking performance in English speaking skill before and after the implementation of Gold Standard Project Based Learning 
The researchers are proposing a qualitative case study to be implemented at an urban government school in Kuala Lumpur. A teacher will be chosen to conduct the project. The teacher must be a major in TESL as this study focuses on English speaking skill. This is to ensure that the teacher is competent with the language skill, pedagogy skills and framework of the CEFR syllabus. 30 participants are chosen through purposive sampling. The participants are pupils from the classes taught by the same teacher that will conduct the project. The participants are intermediate Year Three pupils. Intermediate pupils are the pupils who reached band 3 in speaking skill based on the Classroom Based Assessments. The intermediate proficiency pupils are chosen because they have the basic speaking skills that make the respondents easier to participate in the study. The criteria of the pupils who are able to reach band three are as follow:

- Produces and comprehends simple information on very familiar topics with support from the teacher

- Asks and answers straightforward questions using fixed phrases with support from the teacher

- Participates and manages simple interactions on familiar topics using words, phrases and non-verbal responses from the teacher

(The Manual of Classroom Based Assessments, 2019)

School administrator will be provided with a consent letter to be signed. This would be an official letter proving that permission was granted for the study to be conducted. Other than that, parents' written consent will be obtained as the participants' involvement will be documented. For the documentation, pseudonym will be used to protect the participants' identity.

To ensure the validity and reliability of the data collected, the researcher will use the data triangulation and peer checking technique. The details on data collection tools and data analysis for this study are as follow: (Table 1).

\subsection{PBL in Enhancing English Speaking Skill}

For the proposed project, authentic activities are designed to develop pupils' thinking and problem solving skills that are important in out of school context and to foster learning to learn (Brown, Ash, Rutherford, Nakagawa, Gordon, \& Campione, 1993). For while activities, pupils are expected to get inputs beyond reading or listening in order to provide respond to the needs of the curricular context. Practical activities are tasks that integrate across the curriculum (Thuan, 2018). Though the proposed project focuses more on building pupils' English speaking skill, it also integrates the other three language skills. This study will employ Gold Standard Project Based Learning: Essential Project Design Elements designed by Buck Institute of Education (2015). The proposed project based learning is as follow: (Table 2).

The steps and elements for the proposed project are based on the GSPBL. The project based learning will undergo all steps and contain all elements as stated in the Essential Project Design Element. For the first and second week, all participants will be introduced and learn about the chosen topic in the Year Three 
Table 1. Data collection tools and data analysis.

\begin{tabular}{|c|c|c|c|c|}
\hline $\begin{array}{l}\text { Data } \\
\text { collection } \\
\text { tools }\end{array}$ & Data analysis & $\begin{array}{l}\text { Details on } \\
\text { evaluation }\end{array}$ & Sample questions/evaluation criteria & Notes/remarks \\
\hline Interview & $\begin{array}{l}\text { Interview } \\
\text { response }\end{array}$ & $\begin{array}{l}\text { To get pupils' } \\
\text { insight on } \\
\text { the proposed } \\
\text { project, } \\
\text { learning skill }\end{array}$ & $\begin{array}{l}\text { 1) What is your interview title? } \\
\text { 2) Who did you interview? } \\
\text { 3) How do you conduct the project? } \\
\text { 4) Who helped you? } \\
\text { 5) Do you like doing the project? } \\
\text { 6) Is it fun? } \\
\text { 7) What is difficult for you? } \\
\text { 8) Would you like to do the project again? }\end{array}$ & $\begin{array}{l}\text { Pilot study to be conducted to ensure } \\
\text { the validity of the questions proposed } \\
\text { Transcribed into verbatim } \\
\text { Questions to be validated by three } \\
\text { experts in the education field } \\
\text { The researchers may use the } \\
\text { participants' first/ second language }\end{array}$ \\
\hline Observation & $\begin{array}{l}\text { Observation } \\
\text { notes }\end{array}$ & $\begin{array}{l}\text { To observe } \\
\text { pupils' } \\
\text { speaking skill }\end{array}$ & $\begin{array}{l}\text { 1) Phonological features of speech (rhythm of speech, } \\
\text { intonation) } \\
\text { 2) Rules of language (vocabulary, grammar) } \\
\text { 3) Paralinguistic devices (gestures, facial expressions, } \\
\text { body language, verbal tools) } \\
\text { 4) Communicative functions (identify, understand and use) } \\
\text { 5) Social meaning (formal and informal language, } \\
\text { connotation, conversational principals) }\end{array}$ & $\begin{array}{l}\text { Adapted from: } \\
\text { https://www.teachingenglish.org.uk/ar } \\
\text { ticle/evaluating-speaking } \\
\text { Evaluating Speaking (Kaye, n.d.) }\end{array}$ \\
\hline Documents & $\begin{array}{l}\text { Documents } \\
\text { analysis }\end{array}$ & $\begin{array}{l}\text { Pupils' } \\
\text { performance } \\
\text { level }\end{array}$ & $\begin{array}{l}\text { Pupils' performance level on speaking skill by using criteria } \\
\text { in Classroom Based Assessment }\end{array}$ & $\begin{array}{l}\text { Initial performance level: Band } 3 \text { in } \\
\text { speaking skill } \\
\text { Expected performance level: Band } 4 \\
\text { in speaking skill }\end{array}$ \\
\hline
\end{tabular}

Table 2. Proposed activities for project based learning.

\begin{tabular}{|c|c|c|c|}
\hline Theme/Language skill & Objective(s) & Suggested projects & Outcome products \\
\hline $\begin{array}{l}\text { Year } 3 \text { CEFR syllabus } \\
\text { Module 2: Every day } \\
\text { Speaking skill }\end{array}$ & $\begin{array}{l}\text { To talk about occupation } \\
\text { To talk about everyday activities } \\
\text { To talk about how one gets around }\end{array}$ & $\begin{array}{l}\text { Record an interview video to ask questions and get answers } \\
\text { about certain issues } \\
\text { Example: } \\
\text { 1) Interview a policeman to get opinions on ways for children } \\
\text { to protect themselves from being kidnapped } \\
\text { 2) Interview a dentist to get opinions on dental care } \\
\text { 3) Interview a Physical Education teacher to ask for ways to be } \\
\text { healthy } \\
\text { 4) Interview a neighbour to ask what he/she does for a living }\end{array}$ & Video \\
\hline
\end{tabular}

CEFR syllabus (MoE, 2019). This is to ensure that the key knowledge or the content standard is met by each participant. For the third and fourth week, the teacher helps to create a challenging yet inviting problem for the participants to investigate or explore. It is important to engage the participants to the problems so they feel the need to find the answer and use the information in meaningful ways. The teacher also maintains the authenticity by representing projects based on a real-world scenario which involves participants' concerns, interests and issues in daily lives. Apart from that, participants' voice and choice are being placed first. They have control of selecting the group members, the resources they use, task for each member and the end products they produce. Next, the teacher maintains sustainable inquiries for the participants to use variety of information sources to look for ideas and also promote additional deeper questions. The participants have to work together to gather information about their 
chosen topic and discuss ways to conduct their project. The participants will use variety of ways to gather information apart from reading. Thus, each project is expected to last longer than a few days.

On the fifth week, all groups will show their draft to the class. Here, the teacher and peers provide critique to help the group improve their project. The participants revise and reflect on each other projects to gain information and to enhance their critical thinking. Reflection is also an important element in this process. All participants and teacher will discuss on how and why they are doing the chosen project. This step can be done formally or informally. On the sixth and seventh week, the participants will improve their products through reflection and revision from the previous critique. The teacher puts emphasis on key knowledge, understanding and success skills as during the whole process of working in groups, participants learn to work and solve problem as a team, manage oneself and promote other skill building alongside the ability to think critically and creatively. On the eighth week, participants will present their public product which respond to the question or problem. The presentation of the products intends to motivate, support and meaningfully engage the learning community. For each project, rubrics or models are provided for participants to receive and give constructive comments after each presentation.

Thus, by following the steps and implementing the elements of 2015 Gold Standard PBL, the time duration for the proposed project are as follow: (Table $3)$.

Table 3. Time duration for the proposed GSPBL.

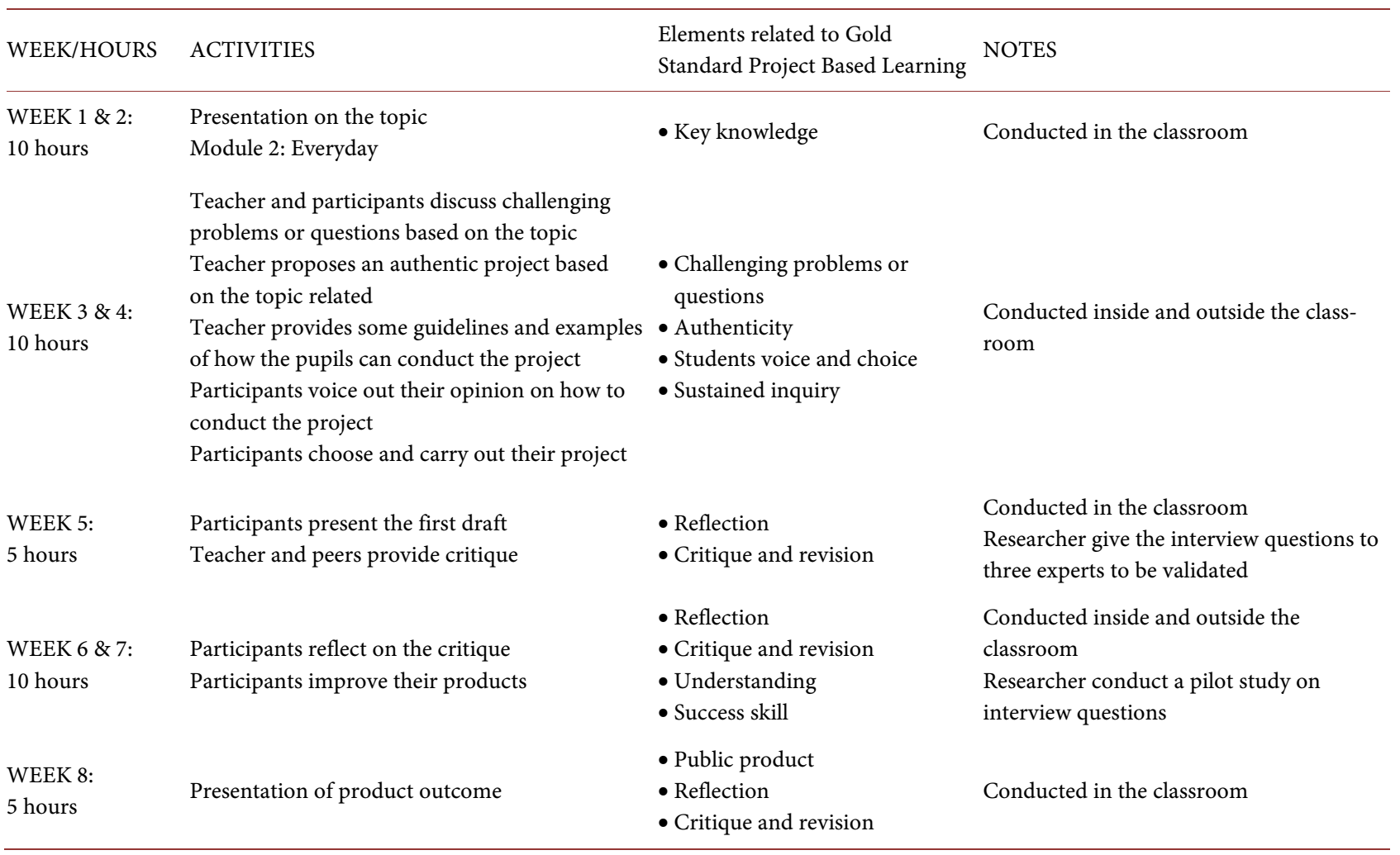




\section{Conclusion}

Gold Standard Project Based Learning can be used as a teaching method to enhance pupils' speaking skill and promote a wholesome learning experience. There are many studies on implementation of Project Based Learning in enhancing language acquisition, with positive impact. Most of the studies affirmed that using PBL approach in learning helps the pupils to develop their language skills (Azura et al., 2012; Newprasit \& Seepho 2015; Shanthi et al. 2015; Zhang, 2015) as cited in Bakar et al. (2019). However, there are limited studies to explore the implementation of Gold Standard Project Based Learning in Malaysian classroom (Aiedah \& Lee, 2012). Hence, the researchers intend to embark on this study.

The findings of this study could seek to discover the implementation of Gold Standard Project Based Learning for English speaking skill. It is intended that with some published findings and research done regarding Gold Standard PBL in Malaysian classroom, it could create a direction for local educators to implement Gold Standard PBL in the teaching and learning process. These findings could give some insights to the educators to understand the elements in Gold Standard PBL.

The data collected and the expected findings focus on the pupils' performance level in English speaking skill. Hence, it is hoped that this study could benefit the educators and pupils in enhancing English speaking skill. Lastly, it is hoped that this study could add value to existing literature of Gold Standard Project Based Learning research.

\section{Conflicts of Interest}

The authors declare no conflicts of interest regarding the publication of this paper.

\section{References}

Aiedah, A. K., \& Lee, K. C. (2012). Application of Project-Based Learning in Students' Engagement in Malaysian Studies and English Language. Journal of Interdisciplinary Research in Education, 2, 37-46.

Azlan, N. A. B., Zakaria, S. B., \& Yunus, M. M. (2019). Integrative Task-Based Learning: Developing Speaking Skill and Increase Motivation via Instagram. International Journal of Academic Research in Business and Social Sciences, 9, 620-636. https://doi.org/10.6007/IJARBSS/v9-i1/5463

Azura, O., Nur, F. T., \& Ida, S. B. (2012). Project-Based Learning: English Carnival in Universiti Kuala Lumpur-Malaysia France Institute. The English Teacher, 41, 27-41.

Bahagian Pendidikan Guru (n.d.). Program transformasi sekolah 2025 (TS25) modul 6: Kefahaman melalui rekabentuk. https://www.tes.com/lessons/djsenhuevA5IpQ/modul-6-ts25-kefahaman-melalui-rekabentuk

Bakar, N. I. A., Noordin, N., \& Razali, A. B. (2019). Improving Oral Communicative Competence in English Using Project-Based Learning Activities. English Language Teaching, 12, 73-84. https://doi.org/10.5539/elt.v12n4p73 
Barron, B., Schwartz, D., Vye, N., Moore, A., Petrosino, A., Zech, L., Bransford, J., \& The Cognition and Technology Group at Vanderbilt University. (1998). Doing with Understanding: Lessons from Research on Problem- and Project-Based Learning. The Journal of the Learning Sciences, 7, 271-311. https://doi.org/10.1080/10508406.1998.9672056

Baruah, T. D. (2012). Effectiveness of Social Media as a Tool of Communication and Its Potential for Technology Enabled Connections: A Micro-Level Study. International Journal of Scientific and Research Publications, 2, 1-10.

http://www.ijsrp.org/research_paper_may2012/ijsrp-may-2012-24.pdf

Baş, G., \& Beyhab, Ö. (2017). Effects of Multiple Intelligences Supported Project-Based Learning on Students' Achievement Levels and Attitudes towards English Lesson. International Electronic Journal of Elementary Education, 2, 365-386.

Baumgartner, E., \& Zabin, C. (2008). A Case Study of Project-Based Instruction in the Ninth Grade: A Semester Long Study of Intertidal Biodiversity. Environmental Education Research, 14, 97-114. https://doi.org/10.1080/13504620801951640

Beneke, S., \& Ostrosky, M. M. (2008). Teachers' Views of the Efficacy of Incorporating the Project Approach into Classroom Practice with Diverse Learners. Young Children, No. 1, 1-9.

Blumenfeld, P. C., Soloway, E., Marx, R. W., Krajcik, J. S., Gudzial, M., \& Palinscar, A. (1991). Motivating Project-Based Learning: Sustaining the Doing, Supporting the Learning. Educational Psychologist, 26, 269-398.

https://doi.org/10.1080/00461520.1991.9653139

Brown, A. L., Ash, D., Rutherford, M., Nakagawa, K., Gordon, A., \& Campione, J. C. (1993). Distributed Expertise in the Classroom. In G. Solomon (Ed.), Distributed Cognitions: Psychological and Educational Considerations (pp. 188-228). Cambridge: Cambridge University Press.

Buck Institute for Education (2019). Gold Standard PBL: Essential Project Design Elements. https://www.pblworks.org/what-is-pbl/gold-standard-project-design

Chomsky, N. (1986). Knowledge of Language: Its Nature, Origin, and Use. Santa Barbara, CA: Greenwood Publishing Group.

Chu, S. K. W., Tse, S. K., Loh, E. K. Y., \& Chow, K. (2011). Collaborative Inquiry Project-Based Learning: Effects on Reading Ability and Interests. Library \& Information Science Research, 33, 236-243. https://doi.org/10.1016/j.lisr.2010.09.008

Cintang, N., Setyowati, D. L., \& Handayani, S. S. D. (2017). Perception of Primary School Teachers towards the Implementation of Project Based Learning. Journal of Primary Education, 6, 81-93.

Evans, C. M. (2019). Student Outcomes from High-Quality Project-Based Learning: A Case Study for PBLWorks. Dover, NH: Center for Assessment.

Faris, A. (2008). The Impact of Project-Based Learning on the Students' Attitudes towards Science among Ninegraders in Hamza Independent School. Analysis, 1-8.

Fauziati, E. (2014). Methods of Teaching English as a Foreign Language (TEFL): Traditional Method, Designer Method, Communicative Approach, Scientific Approach. Surakarta: Era Pustaka Utama.

Heick, T. (2020). 3 Types of Project-Based Learning Show Its Range as a Learning Model. TeachThought.

https://www.teachthought.com/project-based-learning/5-types-of-project-based-learni ng-symbolize-its-evolution

Hertzog, N. B. (2007). Transporting Pedagogy: Implementing the Project Approach in Two First-Grade Classrooms. Journal of Advanced Academics, 18, 530-564. 
https://doi.org/10.4219/jaa-2007-559

Hmelo-Silver, C. E., Duncan, R. G., \& Chinn, C. A. (2007). Scaffolding and Achievement in Problem-Based and Inquiry Learning: Response, 42, 99-107. https://doi.org/10.1080/00461520701263368

Jaya, A., Hermansyah, H., \& Rosmiyati, E. (2019). The Implementation of Project-Based Learning in Increasing Speaking Achievement and Self-Confidence. Indonesian Educational Administration and Leadership Journal, 1, 4-14.

Kaye, P. (n.d.). Evaluating Speaking. British Council Teaching English. https://www.teachingenglish.org.uk/article/evaluating-speaking

Lam, N. T. V. (2011). Project-Based Learning in Teaching English as a Foreign Language. VNU Journal of Science, Foreign Languages, 27, 140-146.

Larmer, J., \& Mergendoller, J. (2015). Why We Changed Our Model of the "8 Essential Elements of $P B L$ ". City: Buck Institute for Education.

Larmer, J., Mergendoller, J., \& Boss, S. (2015a). Gold Standard PBL: Essential Project Design Elements.

https://www.pblworks.org/blog/gold-standard-pbl-essential-project-design-elements

Larmer, J., Mergendoller, J., \& Boss, S. (2015b). Setting the Standard for Project Based Learning. Alexandria, VA: ASCD.

Levine, G. S. (2004). Global Simulation: A Student-Centered, Task-Based Format for Intermediate Foreign Language. Foreign Language Annals, 37, 26-36.

https://doi.org/10.1111/j.1944-9720.2004.tb02170.x

Linse, C. T. (2005). Practical English Language Teaching: Young Learners. New York: McGrawHill ESL/ELT.

Mahsan, I. P., \& Ibrahim, M. N. (2017). Metacognition of Project Based Learning in Digital Art Course among Lecturers: A Case Study in Higher Education Institution, Malaysia. Jurnal Pendidikan Bitara UPSI, 10, 25-36.

Ministry of Education (2018). Laporan tahunan 2017. https://www.padu.edu.my/wp-content/uploads/2018/07/PADU-LAPORAN-TAHUNA N-BM-2017.pdf

Ministry of Education, MoE (2019).CEFR Year 3: English Language Syllabus.

Munawaroh, N. (2017). The Influence of Teaching Methods and Learning Environment to the Student's Learning Achievement of Craft and Entrepreneurship Subjects at Vocational High School. International Journal of Environmental \& Science Education, 12, 665-678.

Newprasit, N., \& Seepho, S. (2015). The Effects of a Project-Based Learning Approach on the Improvement of English Language Skills. Journal of Applied Language Studies and Communication, 1, 16-51.

Nugroho, W. F., \& Anugerahwati, M. (2018). Project-Based Learning: Enhancing EFL Students' Speaking Skill through Vlog. Jurnal Pendidikan: Teori, Penelitian, dan Pengembangan, 4, 1077-1083.

Nunan, D. (1995). Language Teaching Technology: A Textbook for Teachers. London: Phoenix ELT.

Ong, E. T., Ayob, A., Ibrahim, M. N., Adnan, M., Shariff, J., \& Ishak, N. (2016). The Effectiveness of an In-Service Training of Early Childhood Teachers on Stem Integration through Project-Based Inquiry Learning (PIL). Journal of Turkish Science Education, 13, 44-58.

Ong, E. T., Safiee, N., Mat Jusoh, Z., Md Salleh, S., \& Mohamed Noor, A. M. H. (2017). 
STEM Education through Project-Based Inquiry Learning: An Exploratory Study on Its Impact among Year 1 Primary Students. Jurnal Pendidikan Sains Dan Matematik Malaysia, 7, 43-51.

Poonpon, K. (2017). Enhancing English Skills through Project-Based Learning. The English Teacher, 40, 1-10.

Putri, N. L. P. N. S., Artini, L. P., \& Nitiasih, P. K. (2017). Project-Based Learning Activities and EFL Students' Productive Skills in English. Journal of Language Teaching and Research, 8, 1147-1155. https://doi.org/10.17507/jltr.0806.16

Riswandi, D. (2018). The Implementation of Project-Based Learning to Improve Students' Speaking Skill. International Journal of Language Teaching and Education, 2, 32-40. https://doi.org/10.22437/ijolte.v2i1.4609

Sanchez, V. D. P. S. (2019). Project-Based Learning to Develop the Speaking Skill in English. Master's Thesis, Universidad Técnica de Ambato.

Sani, R. A., Manurung, S. R., \& Suswanto, H. (2018). Penelitian Pendidikan. Tangerang: Tira Smart.

Shanthi, W. G., Anniepothen, \& Rao, A. R. (2015). Project Based Learning: An Effective Tool for Developing Aural and Oral Skills of Engineering Students-A Study. In International Conference on Humanities, Literature and Management (pp. 9-11).

Thuan, P. D. (2018). Project-Based Learning: From Theory to EFL Classroom Practice. In Proceedings of the 6th International OpenTESOL Conference (p. 327). Ho Chi Minh City: ResearchGate.

Vaca Torres, A. M., \& Gómez Rodríguez, L. F. (2017). Increasing EFL Learners' Oral Production at a Public School through Project-Based Learning. Profile Issues in Teachers' Professional Development, 19, 57-71. https://doi.org/10.15446/profile.v19n2.59889

Zare-Behtash, E., \& Sarlak, T. (2017). The Effect of Project Based Learning (PBL) on the Components of Speaking Ability of Iranian EFL Beginner Learners. Journal of Applied Linguistics and Language Research, 4, 119-130.

Zhang, Y. (2015). Project-Based Learning in Chinese College English Listening and Speaking Course : From Theory to Practice. Canadian Social Science, 11, 40-44. 